\title{
Formulation, Acceptability and Storage Stability of Appetized Ginger Plum Leather
}

\author{
Manisha Kaushal, Aarti Dhiman, Anil Gupta, Devina Vaidya
}

\author{
Department of Food Science \& Technology, Dr Y S Parmar University of Horticulture \& Forestry Nauni, Solan, HP, India
}

\begin{abstract}
Appetized ginger plum leather was prepared by using different combinations of ginger and plum pulp with varying concentrations of appetizing mixture. The TSS of ginger and plum pulp were raised to $25^{\circ} \mathrm{B}$ by adding sugar and 1.0 to $2.5 \%$ appetizing mixture, followed by drying thin layers in dehydrator $\left(55 \pm 2^{\circ} \mathrm{C}\right)$ to $12-14 \%$ moisture content. The standardization of most palatable recipe was done by evaluating sensory properties and highest score was obtained by ginger: plum (50:50) and 1.5\% appetizing mixture. The appetized leather contained comparatively higher amount of ascorbic acid (13.16mg/100g), total phenols (55.89mg/100g) and antioxidant activity (72.94\%). The leather was found most stable when packaged in laminated aluminium pouches during storage. The leather did not exhibit appreciable changes in titratable acidity, ascorbic acid, total sugars, phenols and antioxidant activity after 6 months. Thus the appetized ginger plum leather can be stored under ambient storage after packing in aluminium laminated pouches.
\end{abstract}

Keywords - Ginger, plum, leather, appetizing mixture, aluminium laminated pouches, antioxidant activity.

\section{INTRODUCTION}

Fruit leather or fruit bar also known as fruit roll means a sheet of dried pureed fruit prepared by blending fruit pulp, fat or milk solids \& other ingredients required for the product which can be mould into desired shape or size (FSSAI 2011). Fruit leather is a confectionery product made by dehydration of fruit puree into leathery sheets and can be prepared from pulpy fruits such as mango (Gujral and Brar 2003), pear (Huang and Hsieh 2005), guava (Vijayanand et al. 2000), longan (Jaturonglumlert and Kiatsiriroat 2010), banana, kiwifruit (Vatthanakul et al. 2010), grape (Maskan et al. 2002), chiku, jackfruit (CheMan and Taufik 1995) and papaya Gowda et al. (1995). Further innovations can be made in the preparation of leathers by adding appetizing constituents like mint, salt, black salt, thyme seed etc. The edible portion of fruit (single or in combination) is pureed, mixed with other ingredients to improve its physicochemical \& sensory characteristics (Phimpharian et al. 2011). Fruit leathers can be dried by using sun drying, oven drying, cabinet drying \& dehydrator drying. Sun drying has traditionally being the process employed for preparing fruit leather from ripe fruits, the process can be unhygienic, lengthy and discolour the products (Teshome 2010). Fruit leathers are dehydrated fruit made from fresh fruit pulp or a mixture of fruit juice and are generally low in calories. Fruit pulp-based fruit leathers are nutritive \& organoleptically acceptable and contains ample quantities of dietary fibers, minerals, vitamins \& antioxidants (Gujral ad Brar 2003; Damodaran et al. 2010; Sharma et. al. 2013).

Ginger (Zingiber officinale Roscoe), generally consumed as a spice and is highly valuable in the international market for its aroma, pungency and high oleoresin content (Onwuka et al, 2002). The major constituents in ginger rhizomes are carbohydrates (50-70\%), lipids (3-8\%), terpenes (Grzanna et al. 2005) and phenolic compounds like gingerol, paradols, shogaol which cause the characteristic odour and flavour of ginger (Harold 2004), aromatic constituents like zingiberene and bisabolene and the pungent constituents like gingerols and shogaols (Tyler 1994). Besides these; amino acids, raw fiber, ash, protein, phytosterols, vitamins and minerals are also present (Langner et al. 1998; Shukla and Singh 2007). Thus ginger can be utilized for value addition and various value added products prepared from ginger are ginger flakes, ginger oil, oleoresin, candy, preserve, paste, and powder (Arya, 2001, Camacho and Brescia, 2009).

Plum (Prunus domestica L.) is one of the important stone fruit crops cultivated in temperate regions of the world, consumed mostly as fresh (Pino and Quijano, 2012). The fruits have attractive colour, flavour and taste and are an excellent source of antioxidants, calcium, magnesium, iron, potassium and fibre besides substantial amounts of vitamin C (Sabarez et al. 1997). The plum fruits with high antioxidant contents can be used for development of different value added products and dried fruit leather is a well known traditional healthy food of Bulgaria and Turkey (Momchilova et al. 2016). The preservation of fruit leather depends on their low moisture content (15-20\%), the natural acidity of the fruit and high sugar content. Major quality parameters associated with dried fruit products are change 
of colour, visual appeal, flavour, shape, texture, microbial load, and retention of nutrient, rehydration properties, water activity and chemical stability (Perera, 2005).

Thus, keeping in mind the therapeutic properties of ginger and the presence of substantial amount of anthocyanins from plum fruits, the present investigations were therefore undertaken to optimize the recipe for the preparation of ginger plum leather by adding palatable concentration of appetizing mixture.

\section{MATERIALS AND METHODS}

The farm fresh ginger and plum fruits were utilized for the preparation of ginger plum leather. The ginger pulp was extracted by the hot break method after adding 30 percent water followed by heating for 60 minutes (Dhiman 2015) and plum pulp was extracted by adding 10 percent water, heating for 15-20 minutes followed by passing the whole mass through the pulper (M/S B. Sen Berry and Co. New Delhi, India). The pulp was preserved by heat pasteurization method (over-flow method) as advocated by Lal and Sharma (1989) and packed in pre-sterilized glass bottles for its use in product development.

Fruit leather/bar was prepared by mixing ginger and plum pulp in different proportions (100:0, 90:10, 80:20, 70:30, 60:40 and 50:50) followed by homogenization and heating. The total soluble solid was raised to $25^{\circ} \mathrm{B}$ by adding cane sugar powder and the mixture was spreaded in a thin layer $(3-6 \mathrm{~mm})$ on the stainless steel trays $\left(30 \times 20 \mathrm{~cm}^{2}\right)$ with a tray load of $440 \mathrm{~g} /$ tray and dried in a mechanical dehydrator at $55 \pm 2^{\circ} \mathrm{C}$. The combinations of ginger plum leather were evaluated on the basis of sensory characteristics and the treatment with higher sensory score was further taken for the standardization of suitable concentration of appetizing mixture. The appetizing mixture prepared by mixing thyme seed powder $(5 \mathrm{~g})$; mint powder $(10 \mathrm{~g})$; salt $(10 \mathrm{~g})$ and black salt $(10 \mathrm{~g})$ was tried in different concentrations of 1.0, 1.5, 2.0 and 2.5 percent. Further, the best treatment combination of ginger plum leather with appetizing mixture was selected on the basis of drying behavior and sensory score. The dried fruit leather was then cut into strips of suitable dimensions $\left(8 \mathrm{~cm}^{2}\right)$ followed by wrapping in a butter paper and packing in aluminium laminated pouches $(20 \mathrm{~g})$ and stored at ambient temperature $\left(14.6-26.1^{\circ} \mathrm{C}\right)$ for further storage studies.

Analysis

Physico-chemical analysis of ginger rhizome, plum fruits and prepared leather was conducted by using standard analytical procedures (Ranganna 1997; Ting and Rouseff 1986; AOAC 1995). Average weight and dimensions of ginger and plum were determined gravimetrically and the results were expressed as $g$ and per cent $(w / w)$ on whole fruit basis. Total soluble solid (TSS) content of fresh and processed products was determined by hand refractometer and sugars were estimated by Lane and Eyon method as detailed in Ranganna (1997). Acidity was determined by titrating the aliquots against $0.1 \mathrm{~N} \mathrm{NaOH}$ solution to a pink end point using phenolphthalein as an indicator (Ranganna 1997). The ascorbic acid content was determined using 2, 6dichloro phenol indophenol dye as per the method given by Ranganna (1997). Total phenols were extracted in 80\% ethanol and were estimated using Folin-Ciocalteau reagent (AOAC 1995). The rate of dehydration per unit time was calculated by placing a weighed quantity of pulp on a stainless steel tray $\left(30 \times 20 \mathrm{~cm}^{2}\right)$ followed by drying in mechanical dehydrator $\left(55 \pm 2{ }^{\circ} \mathrm{C}\right)$ to a moisture content of $12-14 \%(\mathrm{w} / \mathrm{w})$. The loss in weight during drying (\% dwb) was calculated by plotting the moisture on dry weight basis against time in hours (Fellows 1988). The sensory evaluation of fruit leather was done by a semi-trained panel of 7-9 judges for various quality attributes viz., colour, texture, flavour, taste and overall acceptability on 9 point hedonic scale. Data pertaining to sensory evaluation of ginger plum leather was statistically analyzed according to Randomized Block Design (RBD) as described by Mahony (1985) while, the data on chemical analysis was analyzed by following Completely Randomized Design (CRD) Cochran and Cox (1967).

\section{RESULTS AND DISCUSSION}

Physico chemical characteristics of ginger rhizome and plum: The ginger rhizome utilized for product development contained a moisture content of $82.39 \pm 0.05$ percent with total soluble solids as $2.7 \pm 0.10^{\circ} \mathrm{B}$ (Table 1 ). The rhizomes were found to be a good source of ascorbic acid (8.48 \pm $0.53 \mathrm{mg} / 100 \mathrm{~g})$, total phenols $(10.18 \pm 0.03 \mathrm{mg} / 100 \mathrm{~g})$, antioxidant activity $(57.45 \pm 0.60 \%)$, protein $(2.73 \pm 0.06$ $\%)$, crude fibre $(1.41 \pm 0.02 \%)$ and total ash $(1.66 \pm$ $0.02 \%$ ), while oleoresin and oil was noticed to be $5.01 \pm$ 0.05 and $1.63 \pm 0.01$ percent, respectively. These values were in conformity with the result reported by Onyenekwe and Hashimoto (1999), Abeyesekera et al. (2005), Sultan et al. (2005) and Shahid and Hussain (2012).

Further, the plum fruits contribute $13.86^{\circ} \mathrm{B}$ total soluble solids with $2.94 \pm 0.02$ percent of malic acid, with an appreciable amount of ascorbic acid $(18.30 \pm 1.09 \mathrm{mg} / 100$ $\mathrm{g})$, total phenols $(96.66 \pm 2.89 \mathrm{mg} / 100 \mathrm{~g})$, antioxidant activity $(71.6 \pm 0.55 \%)$, crude fibre $(0.07 \pm 0.01 \%)$ and total ash $(0.42 \pm 0.03 \%)$ (Table 1). These values were found in conformity with the result found by Erturk et al. (2009) and Esehaghbeygi et al. (2013). Thus, keeping view the nutritional as well as medicinal properties of ginger and 
plum, they were suitably blended to provide leather with an acceptable acidity, colour and flavour without the addition of exogenous colour, flavour and acid.

Standardization of recipe for leather preparation: The results pertaining to the sensory evaluation of plum ginger leather are presented in Table 2, reveals that the significantly higher scores for colour (8.25), texture (8.20), flavour (7.99), taste (8.00) and overall acceptability (8.50) were received by ginger: plum 50:50 proportion $\left(\mathrm{L}_{6}\right)$. The leather prepared by using 100 percent ginger was rated as least preferred with colour, texture, flavour, taste and overall acceptability scores of 5.16, 5.07, 5.21, 5.81 and 5.11 respectively and was further could not form into leather. However, on the basis of sensory score, 60: 40 proportion $\left(\mathrm{L}_{5}\right)$ was also rated at par with 50:50 $\left(\mathrm{L}_{6}\right)$ but on basis of overall quality and higher yield, the 50: 50 proportion was found superior and thus optimized for further studies.

Drying Behaviour: In comparison to total drying period, the rate of dehydration was very fast during initial period of drying. About 50-55 percent (fwb) of the moisture was lost within the initial 2 to 2.5 hours of drying, thereafter the rate of drying slowed down (Fig 1). It took about 8.0 to 9.30 hours to dry the pulp combination to moisture content of about 13.04 to 13.93 percent (Table 3). The dehydration ratio calculated on the basis of the yield of dried plum ginger leather varied between 3.48: 1 to 3.91: 1 and the maximum yield $(28.76 \%$ ) was noticed in 50:50 proportion and time taken for drying was 9.30 hours.

Standardization of concentration of appetizing mixture in leather: The plum ginger leather combination of 50:50 attaining the highest sensory scores were mixed with appetizing mixture in different concentrations $(1.0 \%, 1.5 \%$, $2.0 \%$ and $2.5 \%$ ) and was subjected to sensory evaluation for the selection of best recipe for the preparation of spiced ginger plum leather. The results pertaining to the sensory evaluation are presented in Table 4 and Fig 2 showed that the score for colour (7.40), texture (8.16), flavour (7.90), taste (7.97) and overall acceptability (8.46) were highest for plum: ginger 50:50 with 1.5 percent appetizing mixture $\left(\mathrm{LA}_{2}\right)$. Although, at par score were given to all combinations by the panellists, but treatment $\mathrm{LA}_{2}(50: 50+$ $1.5 \%$ AM) was liked very much and thus optimized for the development of appetized ginger plum leather and selected for further storage studies.
Drying characteristics: The total time taken for drying by the different plum ginger leather combinations (50:50) containing appetizing mixture in varying concentrations was about 9.45 to 10.40 hours with dehydration ratio of 3.43: 1 to 3.55: 1 and yield ranging between 25.9 to 26.3 percent. The total solids and moisture contents were found in range of 87.33 to 87.67 per cent and 12.42 to 12.67 percent (Table 5).

Physico-chemical characteristics of ginger plum leather: The data presented in Table 6 shows that the appetized ginger plum leather contains slightly higher amount of ascorbic acid $(13.16 \mathrm{mg} / 100 \mathrm{~g})$, phenols $(55.89 \mathrm{mg} / 100 \mathrm{~g})$ and thus having better antioxidant activity $(72.94 \%)$ as compared to leather without appetizing mixture. Thus, the appetizing mixture (1.5\%) adds more value to ginger plum leather.

\section{Storage Studies}

The storage stability of ginger plum leather prepared with or without the addition of appetizing mixture after packing them in aluminium laminated pouches was evaluated at periodic intervals of 0,3 and 6 months at ambient temperature $\left(14.6-26.1^{\circ} \mathrm{C}\right)$.

The plum ginger leather with or without appetizing mixture did not exhibit appreciable changes in total phenols, antioxidant activity and crude fibre content during the entire storage period. The results were in conformity with those obtained by Kaushal et al (2013) in foam mat dried seabuckthorn leather. However, increase in the total soluble solids of the leather is correlated well with the corresponding decrease in the moisture content. The appetized ginger plum leather exhibited 75 percent retention of ascorbic acid $(9.95 \mathrm{mg} / 100 \mathrm{~g})$ as against 70 percent retention $(8.4595 \mathrm{mg} / 100 \mathrm{~g})$ in the leather without appetizing mixture after six months of storage under ambient conditions. However, at end of the storage period the mean ascorbic acid in leather was found to be 9.2 $\mathrm{mg} / 100 \mathrm{~g}$ against its initial value of $12.60 \mathrm{mg} / 100 \mathrm{~g}$ thus representing a reduction of about $22 \%$ (Table 8). The degradation of ascorbic acid during storage is attributed partially to its oxidation and partially to its involvement in browning reactions in the presence of high acidic environment (Clegg 1966). Marginal decrease in total sugars during storage has been attributed to its possible participation in maillard browning reactions (Cheftal et al. 1985).

Further, the sensory quality of ginger plum leather for various attributes during storage is presented in Table 8 . The leather prepared with or without the addition of appetizing mixture was acceptable in all sensory quality 
parameters with a hedonic score more than 7.0 out of 9.0 .

However, the acceptability score exhibited slight decrease with the increase in period of storage. Slight decrease in flavour scores observed during 6 months might be attributed to the loss of aromatic compounds during storage. The ginger plum leather made with the addition of appetizing mixture had a higher score (8.32) for overall acceptability which was non-significantly different from the leather without appetizing mixture (8.35). Further, the sensory score for all organoleptic parameters in the product during six months storage remained above 7.0, thus exhibiting good storage stability of this product.

\section{CONCLUSION}

On basis of sensory evaluation during this study, it can be concluded that among different treatments, ginger: plum 50:50 proportion $\left(\mathrm{L}_{6}\right)$ was found best with overall acceptability score (8.50) and further the plum: ginger 50:50 proportion with 1.5 percent appetizing mixture $\left(\mathrm{LA}_{2}\right)$ optimized for development of appetized ginger plum leather. Thus the method for the preparation of appetized ginger plum leather 50:50 ratio followed by drying and packing in aluminium laminated pouches was found the most appropriate to increase antioxidant activity The developed technology can be commercially explored at industry level for the production of appetized leather and profitable utilization of ginger and highly perishable plum fruits for ensuring better returns to the growers.

Table.1: Physico-chemical characteristics of fresh ginger rhizome (Zingiber officinale) and plum fruit (Prunus domestica)

\begin{tabular}{lcc}
\hline \multicolumn{1}{c}{ Characteristics } & \multicolumn{2}{c}{ Mean \pm SD $^{*}$} \\
\cline { 2 - 3 } & Ginger rhizome & Plum \\
\hline Moisture (\%) & $82.39 \pm 0.05$ & $86.93 \pm 0.09$ \\
TSS $\left({ }^{\circ} \mathrm{B}\right)$ & $2.7 \pm 0.10$ & $13.86 \pm 0.41$ \\
Titratable acidity (\% citric acid for ginger, \% malic acid for plum ) & $0.15 \pm 0.02$ & $2.94 \pm 0.02$ \\
Total sugars (\%) & $1.26 \pm 0.02$ & $9.26 \pm 0.34$ \\
Ascorbic acid (mg/100 g) & $8.48 \pm 0.53$ & $18.30 \pm 1.09$ \\
Total phenols (mg/ 100g) & $10.18 \pm 0.03$ & $96.66 \pm 2.89$ \\
Antioxidant activity (\%) & $57.45 \pm 0.60$ & $71.6 \pm 0.55$ \\
Crude Protein (\%) & $2.73 \pm 0.06$ & $0.6 \pm 0.06$ \\
Crude fibre (\%) & $1.41 \pm 0.02$ & $0.07 \pm 0.01$ \\
Total ash (\%) & $1.66 \pm 0.02$ & $0.42 \pm 0.03$ \\
Oleoresin (\%) & $5.01 \pm 0.05$ & - \\
Oil (\%) & $1.63 \pm 0.01$ & - \\
\hline
\end{tabular}

*All values are the mean of 10 observations, $S D=$ Standard deviation

Table.2: Sensory* evaluation of recipes for the preparation of plum ginger leather

\begin{tabular}{ccccccc}
\hline Treatments & $\begin{array}{c}\text { Plum: ginger } \\
\text { ratio }\end{array}$ & Colour & Texture & Flavour & Taste & $\begin{array}{c}\text { Overall } \\
\text { Acceptability }\end{array}$ \\
\hline $\mathbf{L}_{\mathbf{1}}$ & $100: 0$ & 7.98 & 7.80 & 7.59 & 7.59 & 7.78 \\
$\mathbf{L}_{\mathbf{2}}$ & $90: 10$ & 8.10 & 7.82 & 7.62 & 7.62 & 7.87 \\
$\mathbf{L}_{\mathbf{3}}$ & $80: 20$ & 8.14 & 7.87 & 7.68 & 7.78 & 7.89 \\
$\mathbf{L}_{\mathbf{4}}$ & $70: 30$ & 8.16 & 7.98 & 7.76 & 7.81 & 7.92 \\
$\mathbf{L}_{5}$ & $60: 40$ & 8.20 & 8.16 & 7.92 & 7.91 & 8.00 \\
$\mathbf{L}_{6}$ & $50: 50$ & 8.25 & 8.20 & 7.99 & 8.00 & 8.50 \\
$\mathbf{L}_{7}$ & $0: 100$ & 5.16 & 5.07 & 5.21 & 5.81 & 5.11 \\
& $\mathbf{C D}$ & $\mathbf{0 . 0 4}$ & $\mathbf{0 . 0 3}$ & $\mathbf{0 . 0 2}$ & $\mathbf{0 . 0 8}$ & $\mathbf{0 . 0 3}$ \\
\hline
\end{tabular}

*On 9 point hedonic scale 
Table.3: Effect of different recipes on drying behaviour of plum ginger leather

\begin{tabular}{ccccccc}
\hline Treatments & $\begin{array}{c}\text { Plum: } \\
\text { ginger }\end{array}$ & $\begin{array}{c}\text { Drying } \\
\text { times }\end{array}$ & $\begin{array}{c}\text { Yield } \\
\mathbf{( \% )}\end{array}$ & $\begin{array}{c}\text { Dehydration } \\
\text { ratio }\end{array}$ & $\begin{array}{c}\text { Total solids } \\
\mathbf{( \% )}\end{array}$ & $\begin{array}{c}\text { Moisture } \\
(\boldsymbol{\%})\end{array}$ \\
\hline $\mathbf{L}_{\mathbf{1}}$ & $100: 0$ & 8.00 & 27.10 & $3.91: 1$ & 86.07 & 13.93 \\
$\mathbf{L}_{\mathbf{2}}$ & $90: 10$ & 8.10 & 27.23 & $3.67: 1$ & 86.37 & 13.63 \\
$\mathbf{L}_{3}$ & $80: 20$ & 8.35 & 27.55 & $3.63: 1$ & 86.59 & 13.41 \\
$\mathbf{L}_{\mathbf{4}}$ & $70: 30$ & 8.55 & 28.21 & $3.55: 1$ & 86.72 & 13.28 \\
$\mathbf{L} \mathbf{5}$ & $60: 40$ & 9.15 & 28.70 & $3.48: 1$ & 86.89 & 13.15 \\
$\mathbf{L} 6$ & $50: 50$ & 9.30 & 28.76 & $3.48: 1$ & 86.99 & 13.04 \\
\hline
\end{tabular}

Table.4: Effect of different concentrations of appetizing mixture on *sensory quality of appetized plum ginger leather

\begin{tabular}{|c|c|c|c|c|c|c|}
\hline Treatments & $\begin{array}{c}\text { Plum: Ginger + } \\
\text { \#AM } \quad(\%)\end{array}$ & Colour & Texture & Flavour & Taste & $\begin{array}{c}\text { Overall } \\
\text { Acceptability }\end{array}$ \\
\hline $\mathbf{L A}_{1}$ & $50: 50+1.0$ & 7.36 & 7.94 & 7.86 & 7.88 & 7.62 \\
\hline $\mathbf{L A}_{2}$ & $50: 50+1.5$ & 7.40 & 8.16 & 7.90 & 7.97 & 8.46 \\
\hline $\mathbf{L A}_{3}$ & $50: 50+2.0$ & 7.18 & 7.68 & 7.68 & 7.58 & 7.58 \\
\hline $\mathbf{L A}_{4}$ & $50: 50+2.5$ & 7.13 & 7.62 & 7.64 & 7.47 & 7.42 \\
\hline $\mathrm{CD}_{0.05}$ & & 0.03 & 0.02 & 0.05 & 0.14 & 0.08 \\
\hline
\end{tabular}

* On 9 point hedonic scale

${ }^{\#} \mathrm{AM}=$ Appetizing mixture

Table.5: Effect of different concentrations of appetizing mixture on drying behaviour of spiced ginger leather

\begin{tabular}{ccccccc}
\hline Treatments & $\begin{array}{c}\text { Plum: Ginger + } \\
\text { \#AM (\%) }\end{array}$ & $\begin{array}{c}\text { Drying times } \\
(\mathbf{h r s})\end{array}$ & $\begin{array}{c}\text { Yield } \\
(\boldsymbol{\%})\end{array}$ & $\begin{array}{c}\text { Dehydration } \\
\text { ratio }\end{array}$ & $\begin{array}{c}\text { Total solids } \\
(\boldsymbol{\%})\end{array}$ & $\begin{array}{c}\text { Moisture } \\
(\boldsymbol{\%})\end{array}$ \\
\hline LA1 & $50: 50+1.0$ & 9.45 & 25.90 & $3.55: 1$ & 87.33 & 12.67 \\
LA2 & $50: 50+1.5$ & 10.00 & 26.03 & $3.48: 1$ & 87.36 & 12.64 \\
$\mathbf{L A}$ & $50: 50+2.0$ & 10.15 & 26.10 & $3.44: 1$ & 87.62 & 12.50 \\
$\mathbf{L A 4}$ & $50: 50+2.5$ & 10.40 & 26.30 & $3.43: 1$ & 87.67 & 12.42 \\
\hline
\end{tabular}

\#AM = Appetizing mixture

Table.6: Physico-chemical characteristics of ginger plum leather

\begin{tabular}{lll}
\hline & \multicolumn{2}{c}{ Ginger : Plum } \\
Parameters & $\mathbf{5 0 : 5 0}$ & $\mathbf{5 0 : 5 0}+\mathbf{1 . 5 \%} \mathbf{A M}$ \\
\hline Moisture (\%) & 13.04 & 12.64 \\
Total soluble solids $\left({ }^{\circ} \mathrm{B}\right)$ & 49.07 & 49.02 \\
Titratable acidity $(\%)$ & 2.82 & 2.86 \\
$\mathrm{pH}$ & 3.52 & 3.46 \\
Reducing sugars $(\%)$ & 13.68 & 13.71 \\
Total sugars $(\%)$ & 37.29 & 37.04 \\
Ascorbic acid $(\mathrm{mg} / 100 \mathrm{~g})$ & 12.05 & 13.16 \\
Total ash $(\%)$ & 3.72 & 3.82 \\
Total phenols $(\mathrm{mg} / 100 \mathrm{~g})$ & 53.54 & 55.89 \\
Antioxidant activity $(\%)$ & 72.61 & 72.94 \\
Crude fibre $(\%)$ & 0.41 & 0.42 \\
Salt $(\%)$ & ----- & 1.89 \\
\hline
\end{tabular}


Table.7: Changes in quality characteristics of ginger plum leather during storage at ambient temperature (14.6-26.1 $\left.{ }^{\circ} \mathrm{C}\right)$

\begin{tabular}{|c|c|c|c|c|c|c|}
\hline Parameter & leather & 0 month & 3 month & 6 month & Mean & $\mathrm{CD}_{0.05 \%}$ \\
\hline \multirow[t]{3}{*}{ Moisture (\%) } & $50: 50$ & 13.04 & 12.93 & 12.80 & 12.92 & $\mathrm{~T}=0.03$ \\
\hline & $50: 50+1.5 \% \mathrm{AM}$ & 12.64 & 12.55 & 12.35 & 12.51 & $\mathrm{~S}=0.03$ \\
\hline & Mean & 12.84 & 12.74 & 12.57 & & $\mathrm{~T} \times \mathrm{S}=\mathrm{NS}$ \\
\hline \multirow[t]{3}{*}{ TSS $\left({ }^{\circ} \mathrm{B}\right)$} & $50: 50$ & 49.07 & 50.06 & 50.56 & 49.90 & $\mathrm{~T}=\mathrm{NS}$ \\
\hline & $50: 50+1.5 \%$ AM & 49.02 & 50.02 & 50.49 & 49.84 & $S=0.19$ \\
\hline & Mean & 49.04 & 50.04 & 50.52 & & $\mathrm{~T} \times \mathrm{S}=\mathrm{NS}$ \\
\hline \multirow{3}{*}{$\begin{array}{l}\text { Titratable } \\
\text { acidity }(\%)\end{array}$} & $50: 50$ & 2.82 & 2.60 & 2.38 & 2.60 & $\mathrm{~T}=0.04$ \\
\hline & $50: 50+1.5 \%$ AM & 2.86 & 2.70 & 2.48 & 2.68 & $S=0.04$ \\
\hline & Mean & 2.84 & 2.65 & 2.43 & & $\mathrm{~T} \times \mathrm{S}=\mathrm{NS}$ \\
\hline \multirow[t]{3}{*}{ Total sugars (\%) } & $50: 50$ & 37.29 & 36.01 & 35.49 & 36.26 & $\mathrm{~T}=\mathrm{NS}$ \\
\hline & $50: 50+1.5 \%$ AM & 37.04 & 36.0 & 35.22 & 36.09 & $S=0.55$ \\
\hline & Mean & 37.16 & 36.00 & 35.35 & & $\mathrm{~T} \times \mathrm{S}=\mathrm{NS}$ \\
\hline \multirow{3}{*}{$\begin{array}{l}\text { Ascorbic } \\
\text { (mg/100g) }\end{array}$} & $50: 50$ & 12.05 & 10.14 & 8.45 & 10.21 & $\mathrm{~T}=0.31$ \\
\hline & $50: 50+1.5 \%$ AM & 13.16 & 11.97 & 9.95 & 11.69 & $S=0.03$ \\
\hline & Mean & 12.60 & 11.05 & 9.2 & & $\mathrm{~T} \times \mathrm{S}=0.05$ \\
\hline \multirow{3}{*}{$\begin{array}{l}\text { Total phenols } \\
(\mathrm{mg} / 100 \mathrm{~g})\end{array}$} & $50: 50$ & 53.54 & 53.51 & 53.42 & 53.49 & $\mathrm{~T}=\mathrm{NS}$ \\
\hline & $50: 50+1.5 \% \mathrm{AM}$ & 55.89 & 55.70 & 55.42 & 55.67 & $\mathrm{~S}=\mathrm{NS}$ \\
\hline & Mean & 54.71 & 54.60 & 54.42 & & $\mathrm{~T} \times \mathrm{S}=\mathrm{NS}$ \\
\hline \multirow{3}{*}{$\begin{array}{l}\text { Antioxidant } \\
\text { activity }(\%)\end{array}$} & $50: 50$ & 72.61 & 72.37 & 72.05 & 72.34 & $\mathrm{~T}=\mathrm{NS}$ \\
\hline & $50: 50+1.5 \% \mathrm{AM}$ & 72.94 & 72.65 & 72.30 & 72.63 & $\mathrm{~S}=\mathrm{NS}$ \\
\hline & Mean & 72.77 & 72.51 & 72.17 & & $\mathrm{~T} \times \mathrm{S}=\mathrm{NS}$ \\
\hline
\end{tabular}

$\mathrm{S}=$ Storage, $\mathrm{T}=$ Temperature, $\mathrm{AM}=$ appetizing mixture, $\mathrm{NS}=$ non significant

Table.8: Changes in sensory quality of ginger plum leather during storage at ambient temperature (14.6-26.1 $\left.{ }^{\circ} \mathrm{C}\right)$

\begin{tabular}{|c|c|c|c|c|c|c|}
\hline $\begin{array}{l}\text { Sensory } \\
\text { Characteristics }\end{array}$ & leather & 0 month & 3 month & 6 month & Mean & CD ${ }_{0.05 \%}$ \\
\hline \multirow{3}{*}{ Colour } & $50: 50$ & 8.22 & 8.19 & 8.11 & 8.17 & $\mathrm{~T}=0.05$ \\
\hline & $50: 50+1.5 \%$ AM & 7.40 & 7.34 & 7.28 & 7.34 & $S=0.04$ \\
\hline & Mean & 7.81 & 7.76 & 7.69 & & $\mathrm{~T} \times \mathrm{S}=\mathrm{NS}$ \\
\hline \multirow[t]{2}{*}{ Texture } & $50: 50$ & 8.17 & 8.10 & 8.05 & 8.11 & $\mathrm{~T}=0.05$ \\
\hline & $50: 50+1.5 \% \mathrm{AM}$ & 8.16 & 8.08 & 8.01 & 8.08 & $S=0.04$ \\
\hline \multirow{4}{*}{ Flavour } & Mean & 8.16 & 8.09 & 8.03 & & $\mathrm{~T} \times \mathrm{S}=\mathrm{NS}$ \\
\hline & $50: 50$ & 7.91 & 7.85 & 7.77 & 7.84 & $\mathrm{~T}=\mathrm{NS}$ \\
\hline & $50: 50+1.5 \%$ AM & 7.90 & 7.82 & 7.72 & 7.81 & $\mathrm{~S}=\mathrm{NS}$ \\
\hline & Mean & 7.90 & 7.83 & 7.74 & & $\mathrm{~T} \times \mathrm{S}=\mathrm{NS}$ \\
\hline \multirow[t]{2}{*}{ Taste } & $50: 50$ & 7.99 & 7.93 & 7.84 & 7.92 & $\mathrm{~T}=\mathrm{NS}$ \\
\hline & $50: 50+1.5 \%$ AM & 7.97 & 7.88 & 7.80 & 7.88 & $\mathrm{~S}=\mathrm{NS}$ \\
\hline \multirow{4}{*}{$\begin{array}{l}\text { Overall } \\
\text { Acceptability }\end{array}$} & Mean & 7.98 & 7.90 & 7.82 & & $\mathrm{~T} \times \mathrm{S}=\mathrm{NS}$ \\
\hline & $50: 50$ & 8.48 & 8.43 & 8.35 & 8.42 & $\mathrm{~T}=\mathrm{NS}$ \\
\hline & $50: 50+1.5 \% \mathrm{AM}$ & 8.46 & 8.40 & 8.32 & 8.39 & $\mathrm{~S}=\mathrm{NS}$ \\
\hline & Mean & 8.47 & 8.41 & 8.33 & & $\mathrm{~T} \times \mathrm{S}=\mathrm{NS}$ \\
\hline
\end{tabular}




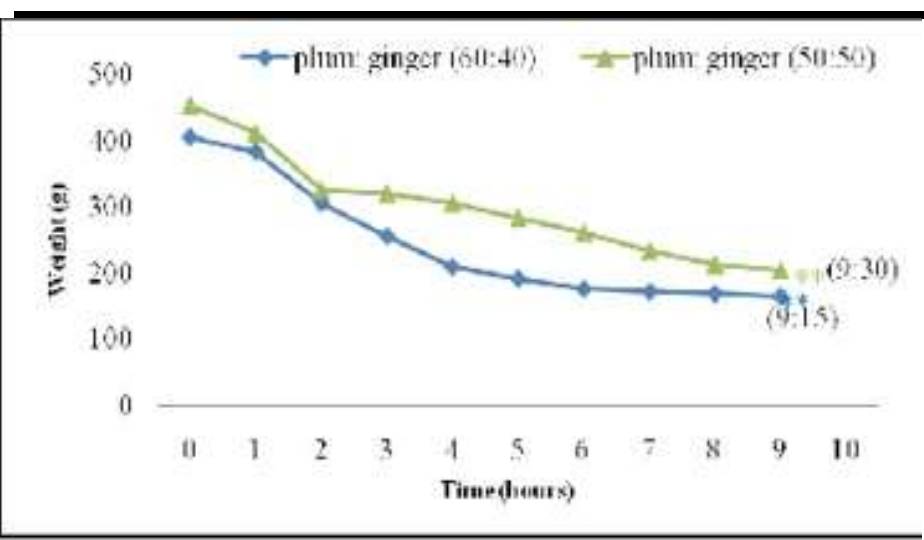

Fig.1: Drying curve of plum ginger leather

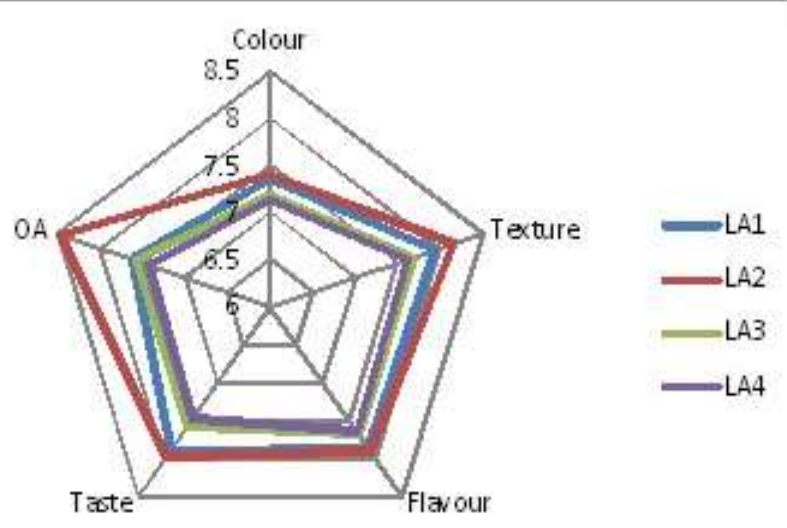

Fig.2: Pictorial representation of sensory scores of appetized ginger leather

\section{REFERENCES}

[1] Abeysekera WKSM, Iueperuma CK, Amunugoda PNRJ, Wijeratnam SW. 2005. Comparison of ginger varieties dried at different temperatures for oil and oleoresin contents. Sri lankan J Agric Sci. 42: 34-42.

[2] AOAC.1995. Official Methods of Analysis, 16th edn. Association of Official Analytical Chemists, Washington DC.

[3] Arya PS. 2001. Ginger Production Technology. Kalyani Publishers, New Delhi. 169p.

[4] Camacho EH, Brescia A. 2009. The Australian ginger industry: Overview of market trends and opportunities. Ginger: The Genus Zingiber. CRC Press, Florida, U.S.A. http://www.daff.qld.gov.au/data/assets

[5] Cheftal JC, Cuq JL, Lorient D. 1985. Amino acids, peptides and proteins. In: Fennema O.R. (ed) Food Chemistry. Marcel Dekker, Inc., New York
[6] CheMan YB, Taufik. 1995. Development and stability of jack fruit leather. Tropical Sci. 35(3): 245-250.

[7] Clegg KM. 1966. Citric acid and the browning of solutions containing ascorbic acid. $\quad J \quad S c i$ Food Agric. 17(12): 546-549

[8] Cochran WG, Cox CM. 1967. Experimental Designs. John Wiley and Sons, Inc., New York.

[9] Damodaran S, Parkin KL, Fennema O R. 2010. AminoAcids, Peptides, and Proteins. In: Fennema O.R.(4 ${ }^{\text {th }}$ edn. $)$ Food Chem., 900 p.

[10]Dhiman A. 2015. Development and evaluation of noble products from ginger. M.Sc. Thesis. Dr Y S Parmar University of Horticulture and Forestry. Nauni, Solan (HP).

[11]Erturk Y, Ercislib S, Tosunc M. 2009. Physicochemical characteristics of wild plum fruits (Prunus spinosa L.). Int J Plant Production. 3(3): 89-92

[12] Esehaghbeygi A, Pirnazari K, Kamali M and Razavi J. 2013. Physical, and mechanical properties of three plum varieties (Prunus domestica L.). Thailand $J$ Agric Sci. 46(2): 95-101

[13]Fellows P. 1988. Food Processing TechnologyPrinciples and Practice. Woodhead Publishing Ltd, Cambridge, England, pp 281-313.

[14]FSSAI. 2011. Food Safety and Standards Authority of India. Food Safety and Standards Regulations, 2011, 435-436.

[15] Gowda D, Ambadan IN, Ramanjaneya KH. 1995. Studies on mango fruit bar preparation. Ind Food Packer. 49(2):17-24

[16] Grzanna R, Lindmark L, Frondoza CG. 2005. Gingeran herbal medicinal product with broad antiinflammatory actions. J Medicinal Food. 8(2):125132.

[17] Gujral HS, Brar SS. 2003. Effect of hydrocolloids on the dehydration kinetics, color, and texture of mango leather. Int J Food Prop. 6 (2):269-279.

[18] Harold M. 2004. Food and Cooking: The Science and Lore of the Kitchen, Scribner, Second Edition, New York, NY, USA, p896.

[19]Huang X, Hsieh FH. 2005. Physical properties, sensory attributes, and consumer preference of pear fruit leather. J Food Sci. 70: E177-E186.

[20] Jaturonglumlert S, Kiatsiriroat T. 2010. Heat and mass transfer in combined convective and far-infrared drying of fruit leather. J Food Eng. 100: 254-260

[21] Kaushal M, Sharma PC, Sharma R. 2013. Formulation and acceptability of foam mat dried seabuckthorn (Hippophae salicifolia) leather. J Food Sci Technol.50(1):78-85 
[22] Lal BB, Sharma TR. 1989. Apricot is a potential fruit crop for processing. Ind Horti. $33 \mathrm{p}$.

[23] Langner E, Greifenberg S, Gruenwald J. 1998. Ginger: history and use. Adv in Therapy. 15 (1):25-44.

[24] Mahony MO. 1985. Sensory evaluation of food. In: Statistical Methods and Procedures. CRC Press, Marcel Dekker, Inc., New York, p510.

[25] Maskan A, Kaya S, Maskan M. 2002. Hot air and sun drying of grape leather (pestil). J Food Eng. 54: 8188.

[26] Momchilova M, Zsivanovits G, Tomova LM, Buhalova D, Dojkova P. 2016. Sensory and texture characterisation of plum (Prunus Domestica) fruit leather. Bul Chem Comm. 48: 428-434.

[27] Onwuka GL, Nwokoha GU, Asumugha GN. 2002. Evaluation of processing methods for the production of ginger drinks. Proceedings of 26th Annual NIFST Conference, Owerri.

[28] Onyenekwe P, Hashimoto S. 1999. The composition of the essential oil of dried Nigerian ginger (Zingiber officinale Roscoe). European Food Res Technol. 209: 407-410

[29] Perera CO. 2005. Selected quality attributes of dried foods. Drying Technol. 23(4):717-730.

[30] Phimpharian C, Jangchud A, Jangchud K, Therdthai N, Prinyawiwatkul W, No HK. 2011. Physicochemical characteristics and sensory optimization of a pineapple leather snack as affected by glucose syrup and pectin concentrations. Int J Food Sci Technol. 46 (5): 972-981

[31] Pino JA, Quijano CA. 2012. Study of the volatile compounds from plum (Prunus domestica L. cv. Horvin) and estimation of their contribution to the fruit aroma. Food Sci Technol (Campinas). 32(1): 76-83

[32] Ranganna S. 1997. Handbook of analysis and quality control for fruit and vegetable products, 2 nd edn. Tata McGraw Hill Pub. Co.Ltd., New Delhi, India

[33] Sabarez H, Price WE, Back P, Woolf LA. 1997. Modeling the kinetics of drying of d' Agen plums (Prunus domestica). Food Chem. 60: 371-382

[34] Shahid M, Hussain F. 2012. Chemical composition and mineral content of Zingiber officinale and Alpiniaallughas (Zingiberaceae) rhizomes. Int $J$ Chemical Biochem Sci. 2: 101-104

[35] Sharma SK, Chaudhary SP, Rao VK, Yadav VK , Bisht TS. 2013. Standardization of technology for preparation and storage of wild apricot fruit bar. $J$ Food Sci Technol. 50 (4): 784-90
[36] Shukla Y, Singh M. 2007. Cancer preventive properties of ginger: a brief review. Food Chem Toxicol. 45(5):683-690.

[37] Sultan MHN, Bhatti, Iqbal Z. 2005. Chemical analysis of essential oil of ginger (Zingiber officinale). Pak J Biol Sci. 8(11): 1576-1578

[38] Teshome B. 2010. Effect of Processing on some quality attributes of mango (Mangifera indica) fruit leather. M.Sc. Chemical Engineering (Food Engineering), Deptt Chemical Engineering Institute of Technology, Addis ababa University School of Graduate Studies, p146.

[39] Ting SV, Rouseff RL. 1986. Citrus fruits and their products-analysis and technology. Marcel Dekker, Inc., New Delhi, 293p

[40] Tyler VE. 1994. The therapeutic use of phytomedicinals, pharmaceutical products Press, New York, NY, USA, 1994.

[41] Vatthanakul S, Jangchud A, Jangchud K, Therdthai N, Wilkinson B. 2010. Gold kiwi fruit leather product development using quality function deployment approach. Food Qual Preference. 21: 339-345.

[42] Vijayanand P, Yadav AR, Balasubramanyam N, Narasimham P. 2000. Storage stability of guava fruit bar prepared using a new process. Food Sci Technol. 33:133-137. 